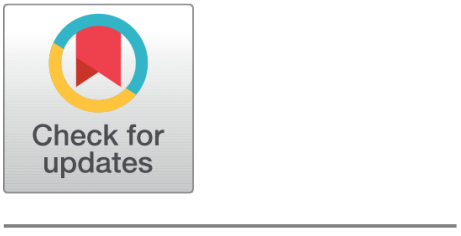

G OPEN ACCESS

Received: 29-03-2020

Accepted: 23-04-2020

Published: 07-05-2020

Editor: Dr. Natarajan Gajendran

Citation: Nguyen QV, Vu AT (2020) Determination of trace Cadmium in water and fish species from estuaries in Tien Hai, Thai Binh, Vietnam By GF-AAS. Indian Journal of Science and Technology 13(12): 1300-1309. https://doi.org/ 10.17485/IJST/v13i12.56

* Corresponding author. Anh-Tuan Vu

School of Chemical Engineering, Hanoi University of Science and Technology, Vietnam

tuan.vuanh@hust.edu.vn

Funding: None

Competing Interests: None

Copyright: ( 2020 Nguyen, Vu. This is an open access article distributed under the terms of the Creative Commons Attribution License, which permits unrestricted use, distribution, and reproduction in any medium, provided the original author and source are credited.

Published By Indian Society for Education and Environment (iSee)

\section{Determination of trace Cadmium in water and fish species from estuaries in Tien Hai, Thai Binh, Vietnam By GF-AAS}

\author{
Quang Vinh Nguyen ${ }^{1}$, Anh-Tuan $\mathbf{V u}^{2 *}$ \\ 1 Department of Chemistry, Thai Binh University of Medicine and Pharmacy, Vietnam \\ 2 School of Chemical Engineering, Hanoi University of Science and Technology, Vietnam
}

\begin{abstract}
Objective: This study aims to determine the trace cadmium in water and fish species from estuaries in Tien Hai, Thai Binh province, Vietnam by graphite furnace atomic absorption spectrometry (GF-AAS). Methodology: The optimal conditions has been investigated by studying the effects of analysis parameters such as spectral line, current of cathode lamp, slit width, furnace temperature, acid concentration and subtracted solution on absorbance. The validation method was evaluated by linear range, accuracy, repeatability, limit of detection (LOD), limit of quantitation (LOQ), recovery $(\mathrm{Re})$, and determination of trace cadmium in water and fish species. Findings: The results showed that the spectral line of $228.3 \mathrm{~nm}$, current of cathode lamp of $4 \mathrm{~mA}$, slit width of $0.5 \mathrm{~nm}$, furnace temperature of $1800^{\circ} \mathrm{C}, \mathrm{HNO}_{3}$ concentration of $1 \%, \mathrm{CH}_{3} \mathrm{COONH}_{4}$ concentration of $1 \%$ were optimal conditions for determination of cadmium. At these conditions, the analytical procedure exhibited the high accuracy and repeatability. The linear range of cadmium was $0-4 \mathrm{ppb}$. The LOD and LOQ values were 0.0058 and $0.019 \mathrm{ppb}$, respectively. Application/Improvements: Determination of the trace cadmium in the water and fish samples was done by the development of analytical procedure. It was applied to determine the water and fish species from Ba Lat and Lan estuaries in Tien Hai, Thai Binh, Vietnam.
\end{abstract}

Keywords: GF-AAS; Trace; Cadmium; Analysis; Fish

\section{Introduction}

The development of industry, agriculture, health care, tourism and trade have made the environment seriously polluted, especially the presence of heavy metals in the soil, water, and ecosystems ${ }^{(1)}$. Waste from factories and craft villages, domestic sewage and even wastewater from agriculture can increase the concentration of heavy metals such as mercury, cadmium, lead, arsenic, etc. in the water and in the creatures at the estuaries ${ }^{(2)}$. Vietnamese government is interested in addressing sources of environmental pollution. The analysis and evaluation of environmental indexes will play an important role in addressing this problem of pollution ${ }^{(3)}$.

In nature, heavy metals exist in air, soil, and water. Heavy metals exist in water in the form of ions or complexes, and they can diffuse to be the widest and furthest 
in the water when compared to air and soil in the environment ${ }^{(4)}$. Under appropriate conditions, heavy metals in aquatic environment can be dispersed into soil and air leading to contamination of crops, vegetables, and fishes ${ }^{(5)}$. Fish are often at the top and the main part of the food chain. It is an essential ingredient in the human diet because it contains a high proportion of protein in the presence of fats, omega-3 fatty acids and vitamins with many minerals. However, according to scientists, fish may be the main source of some toxic heavy metals. And, heavy metals residue in fish reflects high concentrations of toxic heavy metals in water and sediments ${ }^{(6)}$.

Cadmium accumulates mainly in the kidneys for a relatively long time from 10-35 years. Eating foods containing a high content of cadmium will lead to digestive disorders such as nausea, vomiting, abdominal pain, and diarrhea ${ }^{(7)}$. Cadmium also causes calcium metabolism disorders, leading to bone diseases such as bone weakness, bone deformation, bone tissue destruction. In addition, cadmium also causes respiratory damage ${ }^{(8)}$. Long-term occupational exposure to high levels of cadmium may cause symptoms of bronchitis, chronic pneumonia (cough, shortness of breath, chest pain, fever) that contribute to the development of lung cancer. Several studies show that cadmium can cause kidney, lung and prostate cancers ${ }^{(9,10)}$. The International Agency for Research on Cancer (IARC) classifies cadmium and cadmium compounds as Group 1 carcinogens ${ }^{(11)}$. Therefore, the determination of trace cadmium in soil, water, food and environmental samples is becoming a matter priority.

Varied methods have been carried out to determine the trace cadmium. The kinetic method could determine cadmium in water samples with the LOD of $0.1 \mu \mathrm{g} / \mathrm{mL}^{(12)}$. The UV-VIS spectrophotometric method was developed by using the solid phase extraction to analyze cadmium (II), the LOD was $0.07 \mu \mathrm{g} / \mathrm{mL}^{(13)}$. The ICP-OES and F-AAS methods determined cadmium by addition of pre-concentration step with 2,2'-Bipyridyl and erythrosine, the LOD values were 4.0 and $7.75 \mathrm{ng} / \mathrm{mL}$ for ICP-OES and F-AAS, respectively, and the recoveries were more than $93 \%{ }^{(14)}$. ICP-AES with the online adsorption and pre-concentration step via using micro-columns of DPTH-gel and TS-gel could analyze cadmium in water, the linear ranges were 5 to $100 \mathrm{ng} / \mathrm{mL}$ and 10-100 ng/mL and the RSD for ten independent analyses were 1 and 2.5\% for DPTH gel and TS-gel, respectively ${ }^{(15)}$. The AAS method with the sample preparation by $\mathrm{HNO} 3$ and $\mathrm{H}_{2} O$ couldd ${ }_{e}$ termine the cadmium in cockles along the estuary of Sungai Tampok and Sungai Sanglang, showing the cadmium concentration in ranges of 0-4.25 and $03.85 \mu \mathrm{g} / \mathrm{g}$, respectively ${ }^{(16)}$. The graphite furnace atomic absorption spectroscopy (GF-AAS) displayed high sensitivity, selectivity and accuracy for the determination of cadmium in practical samples ${ }^{(15,17,18)}$.

In the current study, analytical procedure by GF-AAS was developed to determine cadmium in water and fish species from estuaries in Tien Hai, Thai Binh, Vietnam. Sample preparation was done using a microwave oven. The effects of acid concentration, substrate solution and releasing reagent on spectral line intensity determined the optimal analysis conditions. The effect of foreign ions on analytical method in addition to statistical methods used in the evaluation of the reliability and accuracy of the analytical method, were carried out.

\section{Experiment}

\subsection{Apparatus and chemicals}

The standard solutions were diluted from a stock solution of $1000 \mathrm{ppm}$ (Merck) to make standard curve. The concentrated solutions $\mathrm{HNO}_{3}$ (Merck, 65\%), $\mathrm{HCl}$ (Merck, 37\%) and $\mathrm{H}_{2} \mathrm{O}_{2}$ (Merck, 30\%) were used without further purification. $\mathrm{NH}_{4} \mathrm{H}_{2} \mathrm{PO}_{4}$ (99\%), $\mathrm{CH}_{3} \mathrm{COONH}_{4}(99 \%), \mathrm{CH}_{3} \mathrm{COONa}(99 \%)$ and $\mathrm{LaCl}_{3}$ (99\%) were used to study the effect of substrate solution to absorbance. Double distilled water, volumetric flask, filter paper, glass beaker, analytical balance (accuracy $\pm 0.0001 \mathrm{~g}$ ), technical weighing (accuracy $\pm 0.01 \mathrm{~g}$ ), and heating plate were used for sample preparation. The absorbance of the sample measured using an Agilent 200 series AA. The samples were prepared by a microwave reaction system (Anton Paar, Austria).

\subsection{Sample preparation}

\subsubsection{Sample collection and preservation}

The water samples were collected by clean plastic cans from two estuaries, Ba Lat and Lan in Tien Hai, Thai Binh, Vietnam, the map of these estuaries is shown in Figure 1. The samples were collected at two times a day, at ebb tide (around 8:00 am) and at high tide (around 16:30 pm). The samples were collected at the different depths from the surface: $0.5 \mathrm{~m}$ (surface layer), $2 \mathrm{~m}$ (middle layer), and $8 \mathrm{~m}$ (bottom layer). And, the samples were collected during the rainy season (July 2019) and dry season (October 2019). The water after sampled from the estuaries were stored at $4^{\circ} \mathrm{C}$ to avoid changing the volume.

The fish samples were collected from boat that has just docked, the fresh fishes were taken into the sampling equipment then labeled the location and time. Three species of fishes such as mullet, croaker, and goby were selected. From the collected fishes, removal of head, viscera, fins and backbone were done and the meat of fishes was crushed by a mill, then thinly spread on a plate and $50 \mathrm{~g}$ of crushed fish was taken from five positions by the diagonal rule. 


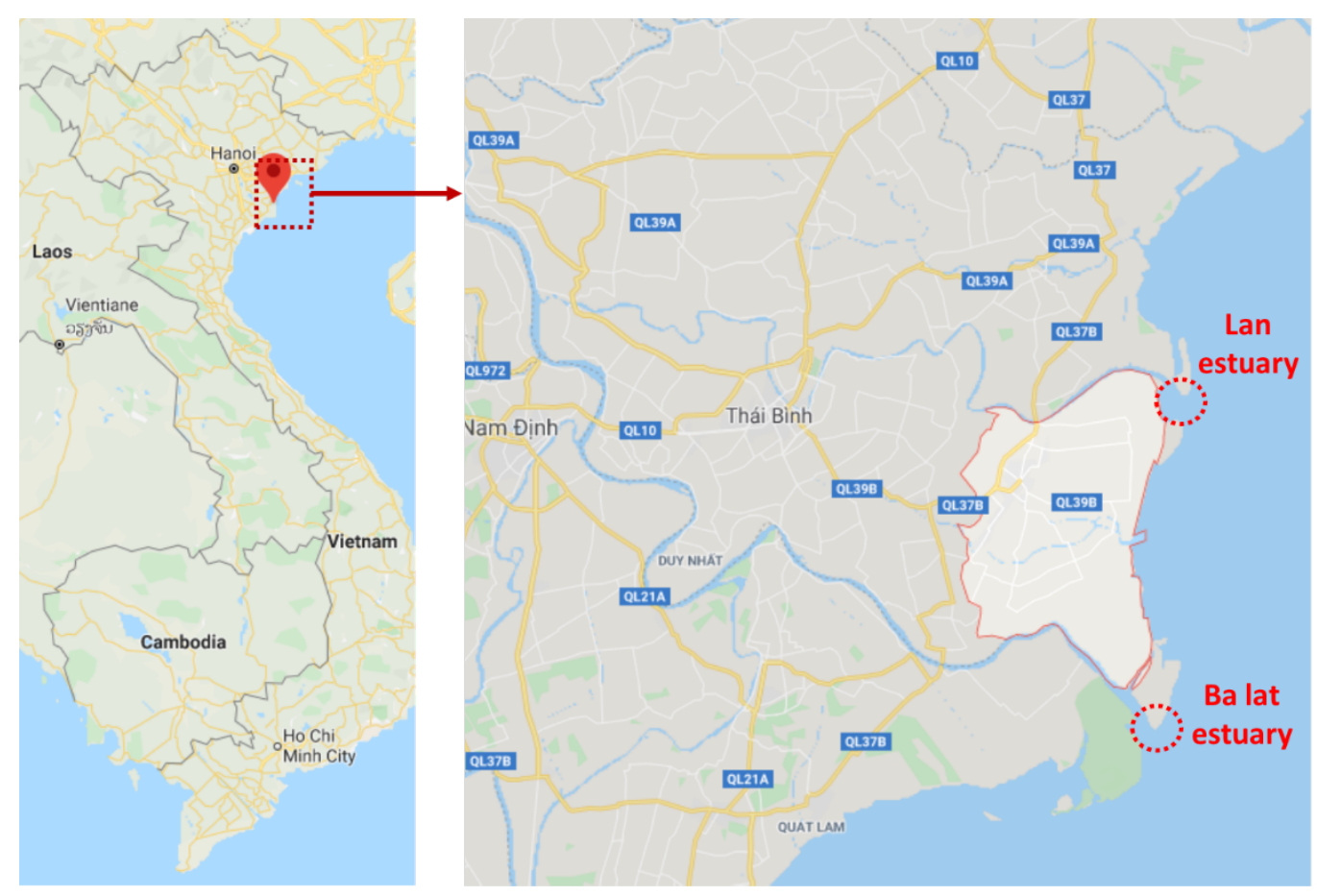

Fig 1. Map of sampling points

\subsubsection{Treatment of samples}

The water samples were filtered and acidified by $\mathrm{HNO}_{3}$ until $\mathrm{pH}<2.0$, then the samples were directly analyzed. Whereas, the treatment of fish samples was relatively complicated, $0.5 \mathrm{~g}$ of milled fish was put into a Teflon chamber, $7 \mathrm{~mL}$ of $\mathrm{HNO}_{3}(65 \%)$ and $1 \mathrm{~mL}$ of $\mathrm{H}_{2} \mathrm{O}_{2}(30 \%)$ were added, the mixture was heated at $\sim 80^{\circ} \mathrm{C}$ for complete removal of $\mathrm{NO}_{2}$. Then the Teflon chamber was placed in a microwave for complete decomposition. After cooling to room temperature, the sample was transferred to a 25 mL volumetric flask and added with $\mathrm{HNO}_{3} 1 \%$ up to the mark. Finally, the fish sample was analyzed by a GF-AAS.

The relative error $(\bar{E} r)$ standard deviation (SD), and relative standard deviation (RSD) were calculated to evaluate the error and repeatability of the measurement by the following equations:

$$
\begin{aligned}
& \bar{E} r=\frac{\left(\left(x_{i}-x_{t}\right) \mid\right.}{x_{t}} \times 100 \\
& S D=\sqrt{\frac{\sum_{1}^{i}\left(x_{i}-\bar{x}\right)^{2}}{(n-1)}}(2) \\
& \operatorname{RSD}=100 \times \frac{S D}{\bar{x}}(3)
\end{aligned}
$$

Where $\bar{x}$ is mean value and $\mathrm{x}_{t}$ is the true or acceptable value.

Limit of detection (LOD) is the lowest quantity of a substance that can be distinguished from the absence of that substance (a blank value) with a stated confidence level (generally 99\%) and limit of quantitation (LOQ) were determined by the following equations:

$$
\begin{aligned}
& \mathrm{LOD}=\bar{x}_{\text {blank }}+3 \mathrm{SD}(4) \\
& \mathrm{LOQ}=\frac{10 \mathrm{LOD}}{3}(5)
\end{aligned}
$$

The content of $\mathrm{Cd}$ in water and fish was determined by the equations (6) and (7):

$$
\begin{aligned}
& C=\frac{C x \times 25}{24.2} \\
& X=\frac{C x \times V}{m}
\end{aligned}
$$


Where $\mathrm{C}(\mu \mathrm{g} / \mathrm{L})$ is the concentration of Cd in the water sample, $\mathrm{X}(\mathrm{mg} / \mathrm{kg})$ is the content of Cd in fish sample, $\mathrm{Cx}(\mu \mathrm{g} / \mathrm{L})$ is the concentration of Cd from standard curves, $\mathrm{V}(\mathrm{L})$ is the volume of sample $(25 \mathrm{~mL})$ and $\mathrm{m}(\mathrm{kg})$ is mass of the fresh fish.

\section{Results and Discussion}

\subsection{Study the effects of analysis parameters}

The cadmium standard solution of $0.6 \mathrm{ppm}$ was used to investigate the effect of spectral lines on absorbance, other conditions were fixed $\left(\mathrm{HNO}_{3} 1 \%\right.$, hollow cathode lamp current of $4 \mathrm{~mA}$, slit width of $0.5 \mathrm{~nm}$, atomization temperature of $1800^{\circ} \mathrm{C}$, and substrate solution of $\mathrm{CH}_{3} \mathrm{COONH}_{4} 1 \%$ ), the results are presented in Table 1. The absorbance at $228.3 \mathrm{~nm}$ was higher but the RSD was lower than those of $326.1 \mathrm{~nm}$. The absorbance and RSD at $228.3 \mathrm{~nm}$ were 0.227 and $0.441 \%$ and these were 0.136 and $0.960 \%$, respectively, for $326.1 \mathrm{~nm}$. Therefore, the spectral line of $228.3 \mathrm{~nm}$ was selected for further analysis.

Table 1. The absorbance of sample at different spectral lines

\begin{tabular}{lll}
\hline \multirow{2}{*}{$\begin{array}{l}\text { Experiment } \\
\text { No. }\end{array}$} & \multicolumn{2}{c}{ Absorbance } \\
\cline { 2 - 3 } & $\mathbf{2 2 8 . 3} \mathbf{~ n m}$ & $\mathbf{3 2 6 . 1} \mathbf{~ n m}$ \\
\hline 1 & 0.227 & 0.137 \\
2 & 0.226 & 0.136 \\
3 & 0.225 & 0.134 \\
4 & 0.228 & 0.137 \\
5 & 0.227 & 0.135 \\
$\bar{X}$ & 0.227 & 0.136 \\
RSD (\%) & 0.441 & 0.960 \\
\hline
\end{tabular}

In order to investigate the effect of the current of hollow cathode lamp on the absorbance, cadmium standard solution of 0.6 ppm was measured at the fixed conditions $\left(\mathrm{HNO}_{3} 1 \%\right.$, spectral line of $228.3 \mathrm{~nm}$, slit width of $0.5 \mathrm{~nm}$, atomization temperature of $1800^{\circ} \mathrm{C}$, and substrate solution of $\mathrm{CH}_{3} \mathrm{COONH}_{4} 1 \%$ ), the current was varied from 2-10 $\mathrm{mA}$. The analytical results are presented in Table 2. The absorbance was the highest and the RSD was the lowest among selected currents, showing the absorbance of 0.227 and RSD of 0.441 at $4 \mathrm{~mA}$. Therefore, the current of hollow cathode lamp of $4 \mathrm{~mA}$ was suitable for further study.

Table 2. The absorbance of sample at different currents of cathode lamp

\begin{tabular}{lllll}
\hline \multirow{2}{*}{$\begin{array}{l}\text { Experiment } \\
\text { No. }\end{array}$} & \multicolumn{4}{c}{ Absorbance } \\
\cline { 2 - 5 } & $\mathbf{2} \mathbf{~ m A}$ & $\mathbf{4} \mathbf{~ m A}$ & $\mathbf{8 ~} \mathbf{~ A A}$ & $\mathbf{1 0} \mathbf{~ m A}$ \\
\hline 1 & 0.096 & 0.227 & 0.112 & 0.137 \\
2 & 0.098 & 0.226 & 0.114 & 0.136 \\
3 & 0.097 & 0.225 & 0.112 & 0.131 \\
4 & 0.096 & 0.228 & 0.113 & 0.133 \\
5 & 0.098 & 0.227 & 0.110 & 0.135 \\
$\bar{X}$ & 0.097 & 0.227 & 0.112 & 0.134 \\
RSD (\%) & 1.031 & 0.441 & 0.893 & 1.493 \\
\hline
\end{tabular}

The slit width was varied from 0.2 to $1.0 \mathrm{~nm}$, other conditions were retained at $\mathrm{HNO}_{3} 1 \%$, spectral line of $228.3 \mathrm{~nm}$, current of hollow cathode lamp of $4 \mathrm{~mA}$, atomization temperature of $1800^{\circ} \mathrm{C}$, and substrate solution $\mathrm{CH}_{3} \mathrm{COONH}_{4} 1 \%$ to investigate the effect of slit width on the absorbance. The results are recorded in Table 3. It was obviously seen that the absorbance at slit width of $0.5 \mathrm{~nm}$ was higher and RSD was lower than those of other slit widths. Therefore, the slit width of $0.5 \mathrm{~nm}$ was chosen for further investigation.

The standard sample Cd (II) $1.1 \mathrm{ppm}$ was measured at the fixed conditions (spectral line of $228.3 \mathrm{~nm}$, hollow cathode lamp current of $4 \mathrm{~mA}$, slit width of $0.5 \mathrm{~nm}$, and substrate solution of $\mathrm{CH}_{3} \mathrm{COONH}_{4} 1 \%$ ), but the atomization temperature was varied from 1800 to $2300^{\circ} \mathrm{C}$. The obtained results are presented in Table 4 . The absorbance at $1800^{\circ} \mathrm{C}$ was higher than those of other temperatures. Therefore, the atomization temperature of $1800^{\circ} \mathrm{C}$ was selected for further investigation.

The effect of acid concentration on the absorbance was carried out by adding the $\mathrm{HCl}$ and $\mathrm{HNO}_{3}$ acids with the concentration range of 1-5\%. The results are presented in Table 5. The absorbance values of samples with the addition of $\mathrm{HCl}$ and $\mathrm{HNO}_{3}$ acids at 
Table 3. The absorbance of sample at the different slit widths.

\begin{tabular}{lllll}
\hline \multirow{2}{*}{$\begin{array}{l}\text { Experiment } \\
\text { No. }\end{array}$} & \multicolumn{4}{c}{ Absorbance } \\
\cline { 2 - 5 } & $\mathbf{0 . 2} \mathbf{~ n m}$ & $\mathbf{0 . 5} \mathbf{~ n m}$ & $\mathbf{0 . 8} \mathbf{~ m m}$ & $\mathbf{1 . 0} \mathbf{~ n m}$ \\
\hline 1 & 0.137 & 0.227 & 0.140 & 0.138 \\
2 & 0.136 & 0.226 & 0.137 & 0.140 \\
3 & 0.134 & 0.225 & 0.145 & 0.137 \\
4 & 0.137 & 0.228 & 0.139 & 0.139 \\
5 & 0.135 & 0.227 & 0.140 & 0.138 \\
$\bar{X}$ & 0.136 & 0.227 & 0.140 & 0.138 \\
RSD (\%) & 0.735 & 0.441 & 2.143 & 0.725 \\
\hline
\end{tabular}

Table 4. The absorbance of sample in different atomization temperatures.

\begin{tabular}{llllll}
\hline Atomization temperature ${ }^{\circ} \mathbf{C}$ & $\mathbf{1 8 0 0}$ & $\mathbf{2 0 0 0}$ & $\mathbf{2 1 0 0}$ & $\mathbf{2 2 0 0}$ & $\mathbf{2 3 0 0}$ \\
\hline Absorbance & 0.2090 & 0.2087 & 0.2085 & 0.2089 & 0.2089 \\
\hline
\end{tabular}

the concentration below $5 \%$ were similar, but the RSD with the addition of $\mathrm{HNO}_{3}$ at $1 \%$ was the smallest among concentrations from 1 to $5 \%$. Thus, the $\mathrm{HNO}_{3} 1 \%$ was chosen for analysis of cadmium sample.

Table 5. The absorbance of sample in $\mathrm{HCl}$ and $\mathrm{HNO}_{3}$ at the different concentrations.

\begin{tabular}{lccc}
\hline Acid & Concentration (\%) & Absorbance & RSD (\%) \\
\hline \multirow{3}{*}{$\mathrm{HCl}$} & 0 & 0.227 & 1.550 \\
& 1 & 0.228 & 1.418 \\
& 3 & 0.225 & 1.471 \\
& 5 & 0.228 & 2.19 \\
$\mathrm{HNO}_{3}$ & 0 & 0.227 & 1.550 \\
& 1 & 0.228 & 0.855 \\
& 3 & 0.223 & 1.709 \\
& 5 & 0225 & 1.754 \\
\hline
\end{tabular}

In some cases, the sample may contain heat resistant substances, it can inhibit the atomization process, leading the reduction of the sensitivity of analytical method. Therefore, the substrates additional vaporizers were added into sample for elimination of the effect of heat resistant substances. In order to investigate the effect of substrate solution on absorbance, the solutions $\mathrm{CH}_{3} \mathrm{COONa}, \mathrm{CH}_{3} \mathrm{COONH}_{4}$, and $\mathrm{LaCl}_{3}$ were added into the sample. The results are presented in Table 6 . In all cases for addition of $\mathrm{CH}_{3} \mathrm{COONa}, \mathrm{CH}_{3} \mathrm{COONH}_{4}$ and $\mathrm{LaCl}_{3}$, the absorbance at $1 \%$ was higher than that of other concentrations. The RSD and absorbance with $\mathrm{CH}_{3} \mathrm{COONH}_{4} 1 \%$ were larger than those with $\mathrm{CH}_{3} \mathrm{COONa} 1 \%$ and $\mathrm{LaCl}_{3} 1 \%$.

Table 6. The absorbance in the different substrates at different concentrations.

\begin{tabular}{ccccccccc}
\hline \multicolumn{3}{c}{$\mathrm{CH}_{3} \mathrm{COONH}_{4}$} & \multicolumn{3}{c}{$\mathrm{CH}_{3}$ COONa } & \multicolumn{3}{c}{$\mathbf{L a C l}_{3}$} \\
\hline Conc. (\%) & Abs. & RSD (\%) & Conc. (\%) & Abs. & RSD (\%) & Conc. (\%) & Abs. & RSD (\%) \\
\hline $\mathbf{0}$ & 0.222 & 1.471 & $\mathbf{0}$ & 0.222 & 1.471 & $\mathbf{0}$ & 0.222 & 1.471 \\
$\mathbf{1}$ & 0.228 & 1.493 & $\mathbf{1}$ & 0.227 & 1.136 & $\mathbf{0 . 5}$ & 0.223 & 2.276 \\
$\mathbf{2}$ & 0.225 & 1.527 & $\mathbf{2}$ & 0.221 & 1.127 & $\mathbf{1 . 0}$ & 0.228 & 1.089 \\
$\mathbf{3}$ & 0.223 & 0.752 & $\mathbf{3}$ & 0.224 & 1.323 & $\mathbf{1 . 5}$ & 0.225 & 1.323 \\
\hline
\end{tabular}

Conc.; Concentration, Abs.: Absorbance

Alkaline Earth metals and some trans-metal foreign ions may affect analytical results, the solutions of $\mathrm{Cd}(\mathrm{II})$ at $0.6 \mathrm{ppm}$ in addition of the cations $\mathrm{Ca}(\mathrm{II}), \mathrm{Mg}(\mathrm{II}), \mathrm{Zn}$ (II) and $\mathrm{Fe}(\mathrm{III})$ at the concentrations of 0-200 ppm were analyzed, the results are presented in Table 7. It could be seen that the absorbance values were relatively similar to each other. In addition, the concentration of these foreign ions in the real samples is relatively lower than $200 \mathrm{ppm}$. Therefore, it could be concluded that these ions did not affect the measurement of cadmium samples. 
Table 7. Effect of interference ions on absorbance

\begin{tabular}{cccccc}
\hline Cation added & \multicolumn{5}{c}{ Concentration (ppm) } \\
\hline $\mathrm{Ca}^{2+}$ & 0 & 50 & 100 & 150 & 200 \\
$\mathrm{Mg}^{2+}$ & 0 & 50 & 100 & 150 & 200 \\
$\mathrm{Zn}^{2+}$ & 0 & 20 & 30 & 40 & 50 \\
$\mathrm{Fe}^{3+}$ & 0 & 20 & 60 & 80 & 100 \\
Absorbance & 0.222 & 0.227 & 0.221 & 0.228 & 0.223 \\
\hline
\end{tabular}

\subsection{Validation method}

\subsubsection{Determination of the linear range}

Since the practical concentration of $\mathrm{Cd}(\mathrm{II})$ in water and fish species was relatively low, the linear range were studied in the concentration range of 0-4 ppb. The obtained absorbance values are presented in Table 8 and the calibration curve is presented in Figure 2. It showed a good linear relationship between the absorbance and concentration of $\mathrm{Cd}(\mathrm{II})$ at the concentration range of $0-4 \mathrm{ppb}$ with the linear regression coefficient of 0.999 . These results revealed that absorbance was directly proportional to the concentration, it meant that Lambert-Beer law was valid.

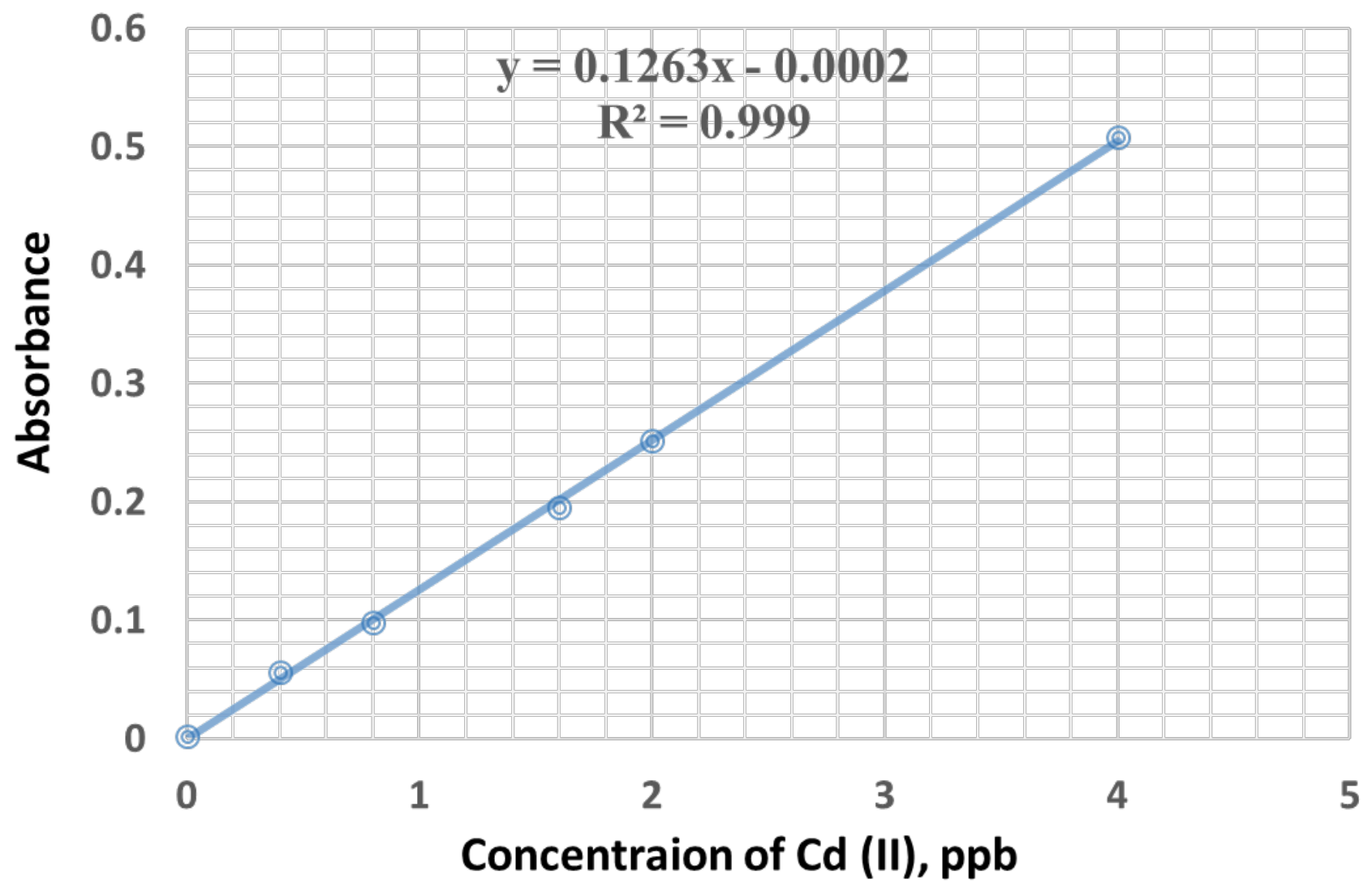

Fig 2. Calibration curve for standard solution Cd (II).

\subsubsection{Accuracy and repeatability of method}

To evaluate the accuracy of the method, the standard samples at 0.4, 1.6 and $4 \mathrm{ppb}$ were prepared. Each sample was measured and repeated in ten times. The results are presented in Table 9. It was showed that the SD values were relatively low and RSD values were in the permissible limitations of $30 \%$ according to AOAC, this meant that the GF-AAS method was highly stable, 
Table 8. Results for the determination of linear concentration range of Cd.

\begin{tabular}{cccccc}
\hline \multirow{2}{*}{ Cd (II) concentration (ppb) } & \multicolumn{3}{c}{ Absorbance } \\
\cline { 2 - 6 } & Abs1 & Abs2 & Abs3 & Average value & RSD (\%) \\
\hline 0 & 0.0017 & 0.0021 & 0.0019 & 0.0019 & 0.53 \\
0.4 & 0.0561 & 0.0556 & 0.0558 & 0.0558 & 0.0980 \\
0.8 & 0.0981 & 0.0980 & 0.0980 & 0.1952 & 0.06 \\
1.6 & 0.1950 & 0.1951 & 0.1955 & 0.2513 & 0.17 \\
2 & 0.2510 & 0.2511 & 0.2518 & 0.5085 & 0.60 \\
4 & 0.5115 & 0.5054 & 0.5085 & & \\
\hline
\end{tabular}

Abs1; Absorbance at thefirst measurement, Abs2; Absorbance at thesecond measurement, Abs3; Absorbance at the third measurement.

accurate, and fully consistent for the determination of trace $\mathrm{Cd}(\mathrm{II})$ in the water and fish species.

Table 9. Accuracy and repeatability for analysis of Cd (II).

\begin{tabular}{lllllll}
\hline Sample & $\mathbf{1}$ & & $\mathbf{2}$ & & $\mathbf{3}$ \\
\hline Concentration of Cd (II) (ppb) & 0.4 & & 1.6 & & 4 & \\
\hline xt (A bs) & 0.05032 & & 0.20188 & & 0.505 & \\
\hline Test & $\mathbf{x i}$ & $\overline{E r}$ & $\mathbf{x i}$ & $\overline{E r}$ & $\mathbf{x i}$ & $\bar{E} r$ \\
1 & 0.0561 & 11.49 & 0.2033 & 0.70 & 0.5115 & 1.29 \\
2 & 0.0556 & 10.49 & 0.2037 & 0.90 & 0.5094 & 0.87 \\
3 & 0.0558 & 10.89 & 0.2010 & 0.44 & 0.5085 & 0.69 \\
4 & 0.0558 & 10.89 & 0.2027 & 0.41 & 0.5085 & 0.69 \\
5 & 0.0523 & 3.93 & 0.2031 & 0.60 & 0.5123 & 1.45 \\
6 & 0.0517 & 2.74 & 0.2036 & 0.85 & 0.5113 & 1.25 \\
7 & 0.0519 & 3.13 & 0.2039 & 1.00 & 0.5107 & 1.13 \\
8 & 0.0515 & 2.35 & 0.2041 & 1.10 & 0.5102 & 1.03 \\
9 & 0.0511 & 1.55 & 0.2043 & 1.20 & 0.5113 & 1.24 \\
10 & 0.051 & 1.35 & 0.2038 & 0.95 & 0.5122 & 1.43 \\
$\bar{x}$ (Abs) & $\mathbf{0 . 0 5 3 3}$ & $\mathbf{5 . 8 8}$ & $\mathbf{0 . 2 0 3 4}$ & $\mathbf{0 . 8 2}$ & $\mathbf{0 . 5 1 0 6}$ & $\mathbf{1 . 1 1}$ \\
SD & $\mathbf{0 . 0 0 2 2 2}$ & & $\mathbf{0 . 0 0 0 9 5}$ & & $\mathbf{0 . 0 0 1 4 0}$ & \\
RSD (\%) & $\mathbf{4 . 1 7}$ & & $\mathbf{0 . 4 7}$ & & $\mathbf{0 . 2 7}$ & \\
\hline
\end{tabular}

\subsubsection{Determination of $\angle O D$ and $\angle O Q$}

The sensitivity of the method was expressed in terms, limit of detection (LOD) and limit of quantification (LOQ). To determine the LOD and LOQ, 20 blank samples were prepared and analyzed at optimal conditions. The obtained absorbance values were used to calculate the standard deviation, $\mathrm{b}$ (intercept of standard curve). LOD and LOQ values determined by equations 4-5 were 0.0058 and $0.019 \mathrm{ppb}$, respectively, as seen in Table 10.

\subsubsection{Determination of recovery method}

The accuracy of method was also evaluated by recovery. The recovery study was carried out via staking the sample at the addition standard levels of 1.6 and $4.0 \mathrm{ppb}$, each level was measured 5 times. The recoveries are presented in Table 11. The recoveries were 98.03 and $98.09 \%$ at concentrations of 1.6 and $4 \mathrm{ppb}$, respectively. These values were compatible with AOAC acceptable range of $40-120 \%$.

\subsection{Application in analysis of real samples}

The water samples were collected from Ba Lat and Lan estuaries at the different seasons and tidal levels. The analysis results are presented in Tables 12 and 13. The concentrations of $\mathrm{Cd}(\mathrm{II})$ at Ba Lat esturary were in range of 0.258-0.918 ppb and the concentrations of Cd(II) from Lan esturary were in the range of $0.133-0.877 \mathrm{ppb}$. These results showed that Cd(II) concentration 
Table 10. Absorbance of 20 bank samples.

\begin{tabular}{cc}
\hline Sample No. & Abs. \\
\hline 1 & 0.0017 \\
2 & 0.0023 \\
3 & 0.0041 \\
4 & 0.0034 \\
5 & 0.0027 \\
6 & 0.0043 \\
7 & 0.0036 \\
8 & 0.0041 \\
9 & 0.0038 \\
10 & 0.0031 \\
11 & 0.0047 \\
12 & 0.0034 \\
13 & 0.0027 \\
14 & 0.0036 \\
15 & 0.0043 \\
16 & 0.0037 \\
17 & 0.0044 \\
18 & 0.0026 \\
19 & 0.0031 \\
20 & 0.0028 \\
$\bar{x}$ & 0.0034 \\
SD & 0.00079 \\
$\mathbf{b}$ & 0.0038 \\
LOD (ppb) & 0.0058 \\
LOQ (ppb) & 0.019 \\
\hline & \\
\hline
\end{tabular}

Table 11. The recoveries of method.

\begin{tabular}{ccc}
\hline Addition of standard level (ppb) & Analysis value (ppb) & Recovery (\%) \\
\hline & 1.5550 & \\
\multirow{2}{*}{1.6} & 1.5622 & \\
& 1.5724 & \\
& 1.5748 & \\
& 1.578 & \\
& 3.9501 & \\
& 3.9454 & \\
& 3.9422 & \\
& 3.8979 & \\
& 3.8820 & \\
\hline
\end{tabular}


in two estuaries of $\mathrm{Ba}$ Lat and Lan at the different seasons and water layers were different, but all values were within the allowed standard of ministry of Natural Resources and Environment (QCVN 10-MT-2015/BTNMT Cd: 50 ppb) and permissible limit of the WHO (2011). The Cd (II) concentration was high in the rainy season due to the phenomenon of leaching from upper stream and it was decreased in the dry season. The Cd(II) concentration at low tide was higher than that of high tide due to the phenomenon of water flowing in to the sea at tide down.

Table 12. The concentration of Cd (II) in water samples of Ba Lat estuary.

\begin{tabular}{cllll}
\hline \multirow{2}{*}{$\begin{array}{c}\text { Water } \\
\text { layer }\end{array}$} & \multicolumn{2}{c}{ Rainy season } & \multicolumn{2}{c}{ Dry season } \\
\cline { 2 - 5 } & High Tide $\bar{c} \pm \mathbf{S D}(\mathbf{p p b})$ & Low Tide $\bar{c} \pm \mathbf{S D}(\mathbf{p p b})$ & High Tide $\bar{c} \pm \mathbf{S D}(\mathbf{p p b})$ & Low Tide $\bar{c} \pm \mathbf{S D}(\mathbf{p p b})$ \\
\cline { 2 - 5 } Surface & $0.281 \pm 0.007$ & $0.314 \pm 0.005$ & $0.308 \pm 0.006$ & $0.258 \pm 0.006$ \\
Middle & $0.408 \pm 0.004$ & $0.416 \pm 0.007$ & $0.326 \pm 0.005$ & $0.392 \pm 0.005$ \\
Bottom & $0.585 \pm 0.006$ & $0.918 \pm 0.004$ & $0.408 \pm 0.006$ & $0.558 \pm 0.008$ \\
\hline
\end{tabular}

Table 13. The concentration of Cd (II) in water samples of Lan Estuary.

\begin{tabular}{cllll}
\hline \multirow{2}{*}{$\begin{array}{c}\text { Water } \\
\text { level }\end{array}$} & \multicolumn{2}{c}{ Rainy season } & \multicolumn{2}{c}{ Dry season } \\
\cline { 2 - 5 } & High Tide $\bar{c} \pm \mathbf{S D}(\mathbf{p p b})$ & Low Tide $\bar{c} \pm \mathbf{S D}(\mathbf{p p b})$ & High Tide $\bar{c} \pm \mathbf{S D}(\mathbf{p p b})$ & Low Tide $\bar{c} \pm \mathbf{S D}(\mathbf{p p b})$ \\
\hline Surface & $0.244 \pm 0.009$ & $0.224 \pm 0.006$ & $0.239 \pm 0.006$ & $0.133 \pm 0.007$ \\
Middle & $0.434 \pm 0.006$ & $0.541 \pm 0.008$ & $0.525 \pm 0.008$ & $0.538 \pm 0.008$ \\
Bottom & $0.811 \pm 0.006$ & $0.877 \pm 0.007$ & $0.654 \pm 0.009$ & $0.808 \pm 0.005$ \\
\hline
\end{tabular}

The fish samples were collected from Ba Lat and Lan estuaries at the different seasons. The analysis results are presented in Table 14. Analysis results showed that the Cd contents in croaker, mullet, and goby fishes from Ba Lat and Lan estuaries at different seasons were different, but these values were within the allowed standard of Ministry of Health (QCVN 8-2:2011/BYT Cd: $0.1 \mathrm{mg} / \mathrm{kg}$ ) and permissible limit of the WHO (2011).

Table 14. The content of Cd in fish species from of Ba Lat and Lan Estuaries.

\begin{tabular}{|c|c|c|c|c|}
\hline \multirow{2}{*}{ Fish species } & \multicolumn{2}{|c|}{ Ba Lat } & \multicolumn{2}{|c|}{ Lan } \\
\hline & $\begin{array}{c}\text { Rainy season } \bar{c} \pm \mathbf{S D}( \\
\mu \mathrm{g} / \mathbf{k g})\end{array}$ & $\begin{array}{c}\text { Dry season } \bar{c} \pm \mathbf{S D}( \\
\mu \mathrm{g} / \mathrm{kg})\end{array}$ & $\begin{array}{c}\text { Rainy season } \bar{c} \pm \mathbf{S D}( \\
\mu \mathbf{g} / \mathbf{k g})\end{array}$ & $\begin{array}{c}\text { Dry season } \bar{c} \pm \mathbf{S D}( \\
\mu \mathrm{g} / \mathbf{k g})\end{array}$ \\
\hline \multicolumn{5}{|l|}{ Croaker fish } \\
\hline & $0.023 \pm 0.001$ & $0.062 \pm 0.003$ & $0.028 \pm 0.001$ & $0.036 \pm 0.001$ \\
\hline \multicolumn{5}{|l|}{ Mullet fish } \\
\hline & $0.021 \pm 0.001$ & $0.023 \pm 0.004$ & $0.023 \pm 0.002$ & $0.028 \pm 0.001$ \\
\hline \multicolumn{5}{|l|}{ Sea goby } \\
\hline fish & $0.023 \pm 0.002$ & $0.022 \pm 0.003$ & $0.027 \pm 0.002$ & $0.022 \pm 0.004$ \\
\hline
\end{tabular}

\section{Conclusion}

The optimal conditions for determination of trace cadmium in water and fish species from Ba Lat and Lan estuaries in Tien Hai, Thai Binh, Vietnam by GF-AAS were followed: spectral line of $228.3 \mathrm{~nm}$, current of cathode lamp of $4 \mathrm{~mA}$, slit width of $0.5 \mathrm{~nm}$, furnace temperature of $1800^{\circ} \mathrm{C}, \mathrm{HNO}_{3}$ concentration of $1 \%, \mathrm{CH}_{3} \mathrm{COONH}_{4}$ concentration of $1 \%$. At the optimal conditions, the analytical method had the high accuracy and repeatability with the RSD values of $4.17,0.47$ and $0.27 \%$ at concentrations of $0.4,1.6,4 \mathrm{ppb}$, respectively. The recoveries of 98.03 and $98.09 \%$ at concentrations of 1.6 and $4 \mathrm{ppb}$, respectively. The foreign ions such as $\mathrm{Ca}(\mathrm{II}), \mathrm{Mg}(\mathrm{II}), \mathrm{Zn}(\mathrm{II})$, and $\mathrm{Fe}(\mathrm{III})$ did not affect analytical method. In addition, water samples and three species of fishes were analyzed. Cadmium was detected in all the samples but the cadmium content in these samples were in the allowed standard prescribed by the Ministryof Natural Resources and Environment (QCVN 10-MT-2015/BTNMT Pb: 50 ppb), and allowed standards of Ministry of Health (QCVN 8-2:2011/BYT Pb: $0.1 \mathrm{mg} / \mathrm{kg}$ ), and permissible limit of the WHO (2011).

\section{References}

1) Vu AT, Xuan TN, Lee CH. Preparation of mesoporous Fe2O3.SiO2 composite from rice husk as an efficient heterogeneous Fenton-like catalyst for degradation of organic dyes. Journal of Water Process Engineering. 2019;28:169-180. 
2) Rodríguez JZ, Ríos SEG, Botero CMR. Content of Hg, Cd, Pb and as in fish species: a review. Revista Vitae. 2015;22(2):148-149. doi:10.17533/udea.vitae.v22n2a09.

3) Tiến TM. 2015.

4) Salwa M, Sara AM, Samia AE, Manal HA, Samia YI, H A, et al.. 2016.

5) Baxter MJ, Burrell JA, Crews HM, Massey RC, McWeeny DJ. A procedure for the determination of lead in green vegetables at concentrations down to $1 \mu \mathrm{g} / \mathrm{kg}$. Food Additives and Contaminants. 1989;6(3):341-349. doi:10.1080/02652038909373789.

6) Asare ML, Cobbina SJ, Akpabey FJ, Duwiejuah AB, Abuntori ZN. Heavy Metal Concentration in Water, Sediment and Fish Species in the Bontanga Reservoir, Ghana. Toxicology and Environmental Health Sciences. 2018;10(1):49-58. doi:10.1007/s13530-018-0346-4.

7) Bakırdere S, Yaroğlu T, Tirık N, Demiröz M, Fidan AK, Maruldalı O, et al. Determination of As, Cd, and Pb in Tap Water and Bottled Water Samples by Using Optimized GFAAS System with Pd-Mg and Ni as Matrix Modifiers. Journal of Spectroscopy. 2013;2013:1-7. doi:10.1155/2013/824817.

8) Bernhoft R. Cadmium Toxicity and Treatment. 2013;p. 1-8.

9) Godt J, Scheidig F, Grosse-Siestrup C, Esche V, Brandenburg P, Reich A, et al. The toxicity of cadmium and resulting hazards for human health. Journal of occupational medicine and toxicology. 2006;(1):22-22.

10) Idrees N, Tabassum B, Abd_Allah EF, Hashem A, Sarah R, Hashim M. Groundwater contamination with cadmium concentrations in some West U.P. Regions, India. Saudi Journal of Biological Sciences. 2018;25(7):1365-1368. doi:10.1016/j.sjbs.2018.07.005.

11) Ramezani Z, Aghel N, N. Amirabedin, Determination of Pb and Cd in Garlic Herb (Allium sativum) Planted in Gilan and Khuzestan Provinces Using Graphite Furnace Atomic Absorption Spectrometry. Jundishapur Journal of Natural Pharmaceutical Products. 2012;7:41-44.

12) Tuan VA, Xuyen NV. Catalytic kinetic method for determination of trace manganese in water. Journal of Science and Technology. 2017;117:5-5.

13) Topuz B, Kabadayi F, Solmaz A. A novel method for the simultaneous determination of Pb (II), Cd (II) and $\mathrm{Zn}$ (II) in environmental water samples. International Journal of Environmental Analytical Chemistry. 2019;99(7):641-652. doi:10.1080/03067319.2019.1607317.

14) Feist B, Mikula B, Pytlakowska K, Puzio B, Buhl F. Determination of heavy metals by ICP-OES and F-AAS after preconcentration with 2,2'-bipyridyl and erythrosine. Journal of Hazardous Materials. 2008;152(3):1122-1129. doi:10.1016/j.jhazmat.2007.07.095.

15) Zougagh M. Determination of cadmium in water by ICP-AES with on-line adsorption preconcentration using DPTH-gel and TS-gel microcolumns. Talanta. 2002;56(4):753-761. doi:10.1016/s0039-9140(01)00605-1.

16) Halit AL, Azman S, Said MIM, Alias N, Ali N. Cadmium and Chromium Accumulation in Cockles along the Estuary of Sungai Tampok and Sungai Sanglang. Journal of Physics: Conference Series. 2018;1049:012043-012043. doi:10.1088/1742-6596/1049/1/012043.

17) dos Santos JM, Quináia SP, Felsner ML. Fast and direct analysis of Cr, Cd and Pb in brown sugar by GF AAS. Food Chemistry. 2018;260:19-26. doi:10.1016/j.foodchem.2018.03.106.

18) Valasques GS, dos Santos AMP, de Souza VS, Teixeira LSG, Alves JPS, de Jesus Santos M, et al. Multivariate optimization for the determination of cadmium and lead in crude palm oil by graphite furnace atomic absorption spectrometry after extraction induced by emulsion breaking. Microchemical Journal. 2020;153:104401-104401. doi:10.1016/j.microc.2019.104401. 